\title{
What Powers for the Federal Reserve?
}

\section{Citation}

Feldstein, Martin. 2010. "What Powers for the Federal Reserve?" Journal of Economic Literature 48 (1): 134-45. https://doi.org/10.1257/jel.48.1.134.

\section{Permanent link}

http://nrs.harvard.edu/urn-3:HUL.InstRepos:41555789

\section{Terms of Use}

This article was downloaded from Harvard University's DASH repository, and is made available under the terms and conditions applicable to Open Access Policy Articles, as set forth at http:// nrs.harvard.edu/urn-3:HUL.InstRepos:dash.current.terms-of-use\#OAP

\section{Share Your Story}

The Harvard community has made this article openly available.

Please share how this access benefits you. Submit a story.

Accessibility 


\title{
What Powers for the Federal Reserve?
}

\author{
Martin Feldstein ${ }^{1}$
}

\begin{abstract}
In this essay, I explain my reasons for the following policy recommendations: (1) The Fed should continue to manage monetary policy as it has in the past, should act as the nation's lender of last resort, should fully supervise the large bank holding companies and their subsidiary banks, and should be given resolution authority over the institutions that it supervises. (2) While a council of supervisors and regulators can play a useful role in dealing with macro prudential risks, it should not replace the central role of the Federal Reserve. (3) The virtually unlimited lending powers that the Fed has recently exercised in creating credit and helping individual institutions should be restricted in duration and subjected to formal Treasury approval backed by Congressional pre-authorization of funds. (4) The Fed's capital rules for commercial banks need to be strengthened by replacing the existing risk-based capital approach with a broader definition of risk and the introduction of contingent capital. (5) Subjecting mortgage lending to a broader range of Federal Reserve regulations and allowing the Fed to deal with non-bank creators of mortgage products would be better than the creation of a new consumer financial protection organization.
\end{abstract}

The roles and responsibilities of the major central banks differ substantially and have evolved significantly over time. The Federal Reserve's operation and authority have also changed frequently in the nearly 100 years since its founding in 1913.

The recent financial crisis, the widespread losses of personal wealth, and the severe economic downturn have raised questions about the appropriate powers of the Federal Reserve and about its ability to exercise those powers effectively. As possible changes are contemplated, it is reasonable to ask what powers should reside with the Federal Reserve, what powers might be given to other government entities, and what actions should be left to free financial markets.

\footnotetext{
${ }^{1}$ Professor of Economics, Harvard University. This essay will appear in the American Economic Association's Journal of Economic Literature, March 2010
} 
The financial sector is already one of the most heavily regulated parts of the American economy. The financial crisis was not due to a lack of regulation but to a failure of supervision and of policy actions more generally.

Although the Fed is an independent agency that is not subject to White House orders, it does not have the Constitutional independence of the Supreme Court or the type of political independence that the Maastricht treaty grants to the European Central Bank. The Federal Reserve was created by the Congress and the Congress has the power to determine what it can and cannot do.

As I considered the wide range of possible changes that have recently been discussed, I have reached three general conclusions. First, the Federal Reserve should remain the primary public institution in the financial sector. Second, the changes that are made should not endanger the Fed's ability to make monetary policy decisions without political interference. Third, its emergency powers should be limited in duration and, in some cases, should require formal Treasury concurrence backed by Congressional pre-authorization.

This essay begins by discussing the Fed's powers in making basic monetary policy. I turn then to the Fed as lender of last resort. I next discuss the Federal Reserve's role as a supervisor of banks and other financial institutions and its role in creating regulations for those entities. I turn finally to the resolution authority that the the Federal Reserve or some other entity might be given to deal with financial institutions that are in distress.

Although I offer my opinion here on many proposals about the Federal Reserve's powers, I believe it is too soon to reach definite conclusions on how all of these issues should be resolved. More research and analysis would be desirable before new legislation causes fundamental institutional changes that would be politically difficult to reverse.

\section{Monetary Policy}

In its basic monetary policy role, the Federal Reserve manages the level of interest rates in pursuit of its dual goals of price stability and maximum sustainable employment. The Fed's traditional policy instrument 
for doing so is open market operations in Treasury securities, generally short-term Treasury bills.

During the recent crisis the Fed has gone beyond its traditional focus on interest rates to providing credit directly for mortgages, credit cards, consumer debt, student loans, auto loans, etc.. It did so using the authority granted to it by section 13(3) of the Federal Reserve Act that provides that, under "unusual and exigent circumstances," the Fed can extend credit to institutions that are not able to "secure adequate credit accommodations from other banking institutions." In addition to providing credit directly for new loans, the Fed also purchased "legacy" loans and existing mortgage backed securities in order to increase the banks' liquidity and the availability of funds in credit markets.

A result of this has been to add some $\$ 2$ trillion dollars of varied assets to the Fed's balance sheet and to create more than $\$ 1$ trillion of excess reserves in the commercial banks. These excess reserves are now dormant, held as deposits at the Federal Reserve under a new arrangement in which the Fed pays interest on such deposits. This vast expansion of the Federal Reserve's balance sheet and of the excess reserves of the commercial banks entails three risks.

First, the Fed could incur losses on its enormous balance sheet if the collateral taken by the Fed experiences declines in value that exceed the "haircuts" (discounts from par) and the risk-sharing financed by the Treasury.

Second, changes in interest rates could also produce substantial financial losses on the Fed's account. The short term interest rate that the Fed pays on deposits could rise substantially (as a result of the Fed's future monetary policy), causing the Fed's financing cost to exceed the interest that it receives on its existing portfolio of long-term securities. In addition, long-term rates might rise, causing declines in the value of the bonds and mortgages that the Fed owns.

Third, the enormous volume of excess reserves of the commercial banks could become a future source of inflationary lending (unless such lending is constrained by the banks' available capital.) The Fed is clearly concerned about this and has discussed various components of a potential exit strategy aimed at preventing such inflation. But all of these techniques 
are untried on the scale of the current excess reserves and in a political environment in which a substantial rise in interest rates could be required while there is near double-digit unemployment. Congressional opposition to such a rise in interest rates could severely test the Fed's willingness to risk its future policy independence in order to prevent current inflation.

In addition to assuming these risks, the Fed's program of making loans and of purchasing specific types of assets (e.g., auto loans or student loans) can be criticized as credit allocation similar to an industrial policy or to the type of fiscal policy normally done by legislation. As such, the Fed's new credit policy is very different from its traditional policy of simply lowering short term rates or the Japanese "quantitative easing" policy of flooding the banks with funds.

Some of the Fed's lending was done under extreme time pressure to avoid what it deemed to be imminent bankruptcies with potentially important systemic consequences (Bear Stearns, American International Group). But most of the lending was part of sustained programs that unfolded over many months. Because of the risks involved, particularly the risk of credit losses, and because of the effects on credit allocation, it would be reasonable to restrict the Federal Reserve's future lending (other than the purchase of Treasury securities) by requiring explicit Congressionally authorized Treasury funding of the longer-term private credit provisions. Such a policy would achieve political accountability for what are now Federal Reserve discretionary policies.

The Fed's rapid lending in financial emergencies could also be made subject to Treasury concurrence by establishing a mechanism for the rapid disbursement of Treasury funds similar to the Exchange Stabilization Fund that the Treasury uses for emergency international transactions.

Federal Reserve officials have recently discussed the possibility of creating longer-term deposit facilities for commercial banks at the Federal Reserve or issuing longer term securities as part of the exit strategy for mopping up excess commercial bank reserves. Although such longer-term borrowing may be useful in the current context, it could have very serious adverse long-term consequences. If the Fed could issue long-term bonds and use the funds raised in that way to finance a variety of long-term lending programs, it would in effect have the ability to give specific long- 
term credits or engage in quasi-spending on particular subjects without Congressional approval.

\section{Lender of Last Resort}

The Federal Reserve's role as the lender of last resort to individual banks is quite separate from its traditional role in managing the level of interest rates. Banks are inherently illiquid institutions, taking deposits that the public can access on demand and lending those funds to businesses that have much longer times to repay. If a large enough number of depositors at any commercial bank wants their funds for any reason, the bank may find itself unable to provide the requested funds quickly enough. In this way, a bank that is solvent, i.e., in which the value of its assets exceeds the value of its liabilities, may find itself illiquid, i.e., having fewer liquid assets than it needs to meet withdrawal requests. To deal with such a situation, central banks act as the lender of last resort, lending to the commercial bank against illiquid collateral. Walter Bagehot, the 19th century editor of the Economist newspaper, provided the classic advice on this subject when he wrote that the central bank should lend freely to a solvent commercial bank but only "at a high rate on good collateral."

In the past year the Fed has extended credit in ways that Bagehot would not have approved. It has certainly loaned against collateral that was not of high quality and that entailed the risk of losses in excess of the haircuts or the Treasury risk sharing guarantees. It also loaned at lower than prevailing market interest rates in order to entice borrowing by the commercial banks. The Fed extended its lender of last resort facility to nonbanks and even to non-financial institutions.

The Fed was able to do this because it had declared the economic conditions in 2008 and 2009 to be the type of section 13(3) "unusual and exigent" circumstances that allowed it to do so. But now that financial markets have returned to much more normal conditions, the Fed should return to the type of lender of last resort transactions that fit within the Bagehot standards. A formal rule requiring the Fed to declare that such circumstances exist if it wishes to invoke 13(3) lending and limiting the period of time in which it could do such lending might be a useful discipline. Fortunately, even without such a rule, most of the unusual lending that the Fed did under 13(3) authority will end in early 2010. But while the new 
lending will end, very large amounts of mortgage bonds and other special assets will remain on the Fed's balance sheet.

\section{Bank Supervision}

In addition to managing interest rates and serving as a lender of last resort the Fed is now the primary supervisor of the nation's bank holding companies. The Fed has been subject to substantial, and I believe justified, criticism for its failure to prevent the behavior in those institutions that contributed directly to the recent financial crisis.

The supervision framework of the Fed and other banking supervisors has long been summarized by the mnemonic CAMEL, indicating that each bank would be judged on the basis of Capital adequacy, Asset quality, Management, Earnings, and Liquidity. In the years before the meltdown that began in 2006 and 2007, Fed officials frequently indicated that bank capital was quite adequate and not a cause for concern. When the crisis hit, it became clear that many banks had inadequate capital and were therefore unable to attract credit in the interbank market or to make loans to commercial borrowers.

Banks were ill prepared for the losses that they incurred when mortgage loans and other bank assets were written down. Banks also had provided little or no capital for off-balance sheet assets (e.g., special investment vehicles) even though in the end the banks were forced by market conditions to recognize the associated losses. This inappropriate treatment of off-balance sheet assets was specifically encouraged by the Basel rules that had been agreed among central banks. Banks also had inadequate capital against the risks associated with other positions including the counter-party risks of various derivatives and credit default swaps.

The inadequate capital was in substantial part a reflection of the misjudged quality of the banks' assets. Mortgage loans made in 2005 and 2006 and the mortgage backed securities based on those loans were formally rated as very low risk (AAA or "super senior") on the basis of the favorable experience of mortgage payments in the early years of the decade when house prices were rising at double digit rates and unemployment was declining. When house prices began to fall in mid2006, many mortgages came to exceed the value of the homes and 
defaults on mortgage payments began to rise. This was exacerbated when rising unemployment increased the number of mortgagees who had difficulty making their monthly payments.

The Federal Reserve and other bank supervisors had failed to recognize that the AAA ratings of the bank assets were based on a faulty model of default risk. Common sense should have indicated by 2005 if not earlier that house prices would stop rising and that defaults would increase when the house price bubble burst. Even if the resulting fall in housing construction had not precipitated a general economic decline, common sense would have pointed to the risk that rising defaults would undermine the value of the banks' capital. But neither the supervisors, nor the lenders, nor the home buyers, nor the economics profession recognized the extent of the bubble.

What are the implications of this failure of supervision for the future role of the Federal Reserve as a bank supervisor? That question can be divided into two broad issues: What new regulations are needed? And what role should the Federal Reserve and other government entities play in enforcing these regulations? Since this essay is about Federal Reserve powers, I begin with the role of the Fed and then turn to the appropriate changes in regulations.

The Fed was, of course, not alone in missing this risk and therefore in misjudging capital adequacy and asset quality. The nation's commercial banks are now subject to supervision by four separate groups of supervisors.

- (1) The Federal Reserve supervises all bank holding companies. Bank holding companies are financial corporations that include a bank and other businesses like brokerage firms. Although the Fed has responsibility for the bank holding company and the bank within it, the Gramm-Leach-Bliley Act of 1999 limits the role of the Federal Reserve in supervising the banks within the bank holding companies.

- (2) The Office of the Controller of the Currency (OCC), a part of the Treasury Department, supervises individual banks that are not part of bank holding companies as well as some of the bank subsidiaries within the bank holding companies. The OCC supervises all national banks (as 
contrasted with state chartered banks) which include virtually all of the large banks that failed in the recent crisis.

- (3) The Federal Deposit Insurance Corporation (FDIC) is the primary supervisor for the more than 5,000 banks that are not part of the Federal Reserve System and for the state chartered savings banks.

- (4) The state banking authorities supervise the commercial banks that have state charters, with responsibility going to the state authority where the bank is headquartered.

Despite this multiplicity of supervisors, or perhaps because of it, none of the supervisors anticipated the problem and acted to stop it from occurring.

Against this background, I will consider four questions about the role of the Federal Reserve, and of the government more generally, as supervisors of banks and other financial institutions:

-- Should financial supervision be transferred from the Federal Reserve and the other supervisors to a new supervisory entity like the British Financial Services Authority?

-- If such a new supervisory entity is not created, which banks should be supervised by the Federal Reserve and which by other supervisory entities?

-- Should the Federal Reserve supervise non-bank institutions that are systemically important?

-- How should the supervision of individual banks be related to the supervision of the financial system as a whole, i.e., to what has been called "macro prudential supervision"?

(1) Should bank supervision be transferred from the Federal Reserve and other current supervisors to a new supervisory agency like the British Financial Services Authority? 
If we were starting today to design the supervision of the financial sector it would be tempting to create a financial supervisory authority that would deal with all financial institutions, judging the adequacy of their capital, the quality of their assets, the risks associated with other contractual positions, etc.. Such a new authority might also be charged with assessing the risks to the financial system as a whole.

The British experience with the Financial Services Authority (FSA), created in 2000, raises serious doubts about this approach. The FSA and the British government more generally failed to identify and prevent the problems that the financial supervisors should have spotted. There is general agreement that the coordination between the FSA, the Bank of England, and the British Treasury was very poor. The Conservative party, now in opposition but expected to win the next general election, has said that it would revert to the old system of supervision by abolishing the FSA and reassigning supervisory power to the Bank of England.

The European Central Bank does not have supervisory authority over the commercial banks of the Eurozone and the individual national banks (like the Banque de France and the German Bundesbank) that do provide supervision did not prevent the combination of poor assets, risky obligations, and inadequate capital that contributed to the financial problems within the European Economic and Monetary Union.

Federal Reserve officials make the argument that the Fed should retain supervisory authority because the Fed's resulting intimate knowledge of the banks provides information that is helpful in making monetary policy decisions. While all relevant information is potentially helpful and access to information about loan demands and lending practices could be particularly helpful, it does not seem necessary for the Federal Reserve to supervise all of the bank holding companies, let alone all of the 8000 commercial banks in the United States, to have that information. Moreover, the tens of thousands of individual bank examiners cannot be an efficient way to collect information and deliver it to the Federal Reserve officials who are responsible for monetary policy.

Although the Fed has had supervisory oversight of the bank holding companies, including the bank holding companies that contain all of the major banks (including Bank of America, Citibank, JPMorgan-Chase, etc), it failed to anticipate the financial crisis and the economic downturn. Even in 
the late summer of 2007, senior Federal Reserve officials were asserting that the subprime mortgage problem was a relatively minor issue without serious macroeconomic implications. Yet even by that time outside observers saw the financial fragility and cyclical forces that led to the major downturn that officially began in December 2007.

A supervisory authority can only be as good as its professional staff. The Federal Reserve has a reputation and a tradition that allows it to attract and retain high quality supervisory staff. A new agency would have to start from scratch to recruit and train the supervisory staff. While many would no doubt come from the Federal Reserve, starting a new supervisory body with no past and an uncertain future would clearly be a disadvantage.

A policy decision to leave the Federal Reserve with its current supervisory responsibilities, or even to expand its responsibilities, should not be regarded as an approval of the performance of the current system. The Federal Reserve should be reorganized to put more emphasis on supervision, particularly of the larger banks that are now located in just a few of the Federal Reserve districts. The Fed now classifies the 25 commercial banks with the largest amounts of assets as "large." Each of these large banks has assets of more than about $\$ 50$ billion and together they account for more than half of all the assets of the banking sector.

The nature of the Fed's supervision should also be changed to assess better the adequacy of the bank's capital, the true quality of its assets, and the risks inherent in its various contractual obligations. The Fed itself should also monitor the practices of other countries to learn what could be done to strengthen our supervisory actions.

2. Which banks should the Federal Reserve supervise? What on-going role should there be for the state bank supervisors, the OCC and the Federal Deposit Insurance Corporation (FDIC)?

As noted above, the Fed now supervises all of the bank holding companies while the state banking authorities supervise the banks within the holding companies that have state banking charters and the OCC supervises the banks within those holding companies that have national charters. 
If it is decided not to create a new national supervisory body, the Fed should retain authority over the bank holding companies that it currently supervises, particularly the large ones with assets of more than $\$ 50$ billion. It would clarify and strengthen the supervisory arrangement if the Fed had complete responsibility for those institutions, replacing the state authorities and OCC in dealing with the banking subsidiaries within those bank holding companies. The remaining banks and bank holding companies are much easier to supervise. These could be left to the state authorities and the OCC, allowing the Fed to focus on the small number of systemically important institutions.

It would be desirable to strengthen the information flow among the different regulators to focus on information that is relevant for macroeconomic policy. At the current time, there is considerable concern about the willingness and ability of local and regional banks to lend to their small and medium size business customers. Many of these banks have considerable commercial real estate loans on their books that might default in coming years, eroding the banks' capital. Although the data that are now regularly reported to the Federal Reserve show declining commercial and industrial loans, it is not clear whether this is because of reduced loan demand or a decreased willingness of the banks to lend. The supervisors of those banks could gather additional information that would be useful for monetary policy and, more generally, for policy officials in the Treasury, the Administration, and the Congress.

The Federal Deposit Insurance Corporation (FDIC) plays an important role in insuring deposits at its member banks and in dealing with failed banks. Nearly 150 banks failed in 2009 and more might do so in 2010. The possibility of individual bank failures does not instigate a run on those banks or other institutions because depositors are insured up to $\$ 250,000$ and business checking balances are fully insured. When a bank fails because its liabilities exceed the value of its assets, the FDIC is generally able to arrange for that institution to be merged or acquired so that it can reopen almost immediately.

The FDIC has recently asked to become a more general primary bank supervisor on the grounds that it is responsible for resolving bank failures. There might be a plausible case for allowing the FDIC to replace the state and OCC supervisors in dealing with those banks that are not supervised by the Federal Reserve. Because it provides compensation 
when a bank fails, the FDIC has a strong stake in reducing the risk of failures and therefore a strong incentive for careful supervision. But there is a danger that the FDIC would be overly cautious in its supervision to protect its insurance fund, causing inappropriate restrictions on lending during business cycle contractions.

If the state and OCC supervisors continue in their current supervisory roles there would be little reason for the FDIC to duplicate that supervision. The FDIC can exercise its ability to deal with the relatively small number of banks that fail without supervising all banks. The FDIC should become the supervisor of those banks not supervised by the Fed only if they replace the state and OCC supervisors.

(3) Should the Federal Reserve supervise nonbank institutions that are systemically important?

Recent experience has shown that a variety of nonbank institutions can create substantial risk for the financial system. Lehman Brothers, AIG, and General Electric Finance are clear examples of how particular activities of investment banks, insurance companies and even non-financial corporations can create substantial systemic risks. It seems clear in retrospect that the portfolio activities of such institutions do need careful supervision by experienced supervisors. If a general financial stability agency is not created, the Federal Reserve seems more appropriate than a separate stand alone supervisor for these institutions. Their investment assets and contractual liabilities are in many cases similar to those of the large banks and are traded in the same markets.

(4) How should the supervision of individual banks be related to the supervision of the financial system as a whole, i.e. to what has been called "macro prudential risk?"

Bank supervisory agencies have historically been tasked with supervising individual banks rather than the banking system as a whole. It is now generally agreed that a more macroeconomic perspective is needed to deal with the systemic risks of the type caused by the bubble in real estate prices or the risks implied by credit default swaps. 
The Federal Reserve should develop a formal mechanism for incorporating systemic financial risk in its monetary policy deliberations in addition to its focus on traditional business cycle risks, inflation risks, and risks associated with individual large financial institutions. One of the clear mistakes of the Federal Reserve's monetary policy in 2002 and 2003 was focusing exclusively on the tradeoff between the risk of inadequate demand (i.e., the unemployment-deflation risk) and the risk of inflation but not on the potential impact of its low interest policy on asset prices with the resulting risk of a future bursting bubble.

It would be good if the staff presentations at each meeting of the Federal Open Market Committee (FOMC) included a section on new developments of potential systemic risks, including changes in asset prices, exchange rates, household and business debt and liquidity ratios, etc..

There has been considerable discussion about whether macro prudential risk might instead be assigned to an interagency committee rather than to the Federal Reserve. A committee that included the FDIC, other bank supervisors, and perhaps the Securities and Exchange Commission (SEC) and the Commodity Futures Trading Commission (CFTC) could bring together useful information that is not currently considered as a whole. The Treasury Department's Undersecretaries for International and Domestic Finance and the head of the Council of Economic Advisers could also contribute usefully to this monitoring activity. But overall responsibility for such macro prudential monitoring cannot be given to a committee but needs to be assigned to a particular organization that should also be tasked with developing and implementing plans to deal with those macro prudential risks that are identified. This responsibility should rest with the Secretary of the Treasury or the Chairman of the Federal Reserve.

\section{What Regulation is Needed?}

The financial sector in general and the banking industry in particular are already among the most heavily regulated parts of the American economy. The Fed has the power to set capital requirements and to establish limits on different types of credits and would like to regulate bank compensation policies as well. The first two of these need to be strengthened while the third is not likely to be helpful. 


\section{Capital Ratios}

The most important of the Federal Reserve's financial regulations applies to capital adequacy standards. These rules were shaped by the Basel Committee but final rule-making authority rests with the Federal Reserve and the other individual central banks. A key feature of the capital standard has been the use of risk-weighted assets as the basis for determining each bank's required capital. Some assets on the bank's balance sheet are regarded as riskier than others and the bank is therefore required to have more capital to offset the risk of losses on those assets. A bank is deemed to have "adequate capital" if its ratio of Tier 1 capital (essentially the value of its common and preferred equity) to its riskweighted assets exceeds 4 percent and to be well capitalized if that ratio exceeds 8 percent.

A serious problem with this approach is the weights associated with different types of assets. Remarkably, residential mortgage debt is deemed to be much less risky than corporate loan debt. A dollar of residential mortgage debt is given a weight of one-half relative to that of corporate debt. No distinction is made about the quality of the mortgage itself (e.g., the loan-to-value ratio, the credit rating of the borrower, etc..).

A further problem is the focus on potential losses on balance sheet assets as the primary source of risk. Inadequate attention was therefore given to risks associated with off-balance sheet positions including credit lines, credit default swaps, other derivative positions, and special investment vehicles. The Federal Reserve should be required to develop a more sophisticated measure of the risks of banks' positions to replace the current capital asset ratio standards.

The Federal Reserve has recently been shifting attention from Tier 1 capital to a narrower measure of tangible equity capital. It has also augmented its traditional capital requirements with "leverage ratio" requirements that relate Tier 1 capital to total assets with no weighting adjustment. While this corrects the previous underweighting of residential real estate loans, it does nothing to deal with differences in loan quality or with the risks and exposures that result from other types of contractual obligations. 
The Fed is currently exploring other measures of risk and of capital. It is also considering contingent capital arrangements in which certain fixed income obligations of the banks would automatically convert to common equity when the regular capital ratio drops below a specified level.

\section{Credit Limits}

The Federal Reserve has the authority to set margin requirements for stock purchases and to raise those requirements when it wants to signal that it thinks that equity markets have become too speculative. It has not used that power in recent decades.

The Fed also has had the ability to regulate the minimum downpayment and loan conditions for automobile buyers but has not used that authority.

Potentially more important than either of these would be regulations on residential real estate loans. Minimum downpayment requirements of the type used in other countries would have prevented the severe loan-tovalue ratio problem that has contributed to the real estate crisis. Other restrictions on mortgage lending, e.g., on the use of temporarily low 'teaser' interest rates, would also have prevented a large number of mortgage defaults.

These powers to limit residential lending could be vested in the Treasury rather than the Federal Reserve. But the very visible impact on households of changes in these standards suggests that it would be better if these powers were given to the less politically sensitive Federal Reserve.

\section{Regulating Compensation}

A more contentious form of regulation proposed by the Fed deals with compensation. The Fed argues that the current system of salaries and bonuses for asset managers and loan officers in commercial banks encourages excessive risk taking and that the Fed should therefore create rules about the form (but not the level) of compensation that would be designed to reduce excessive risk taking. The general form of the proposed rules is to require banks to delay compensation for a number of years and/or to require that some of that compensation be given in the form of equity that can only be sold after a period of time. 
It is not clear why the Fed (or any other government entity) should be given this power. There are four objections to allowing the Fed to do this.

First, since excessive risk taking would cause losses at the individual bank, the bank's management has a very strong incentive to design compensation systems that properly balance bank profits and risk taking. Only in a very small number of cases would the losses cause a failure of the bank with negative externalities for the financial sector as a whole. The regulation of salaries by the government or the Fed might distort risk-taking in counterproductive ways, e.g., by encouraging more short-term investments because they are resolved quickly.

Second, giving shares in the bank as compensation to an individual bank trader or loan officer would only affect that individual's incentives to the extent that that individual's behavior could have an appreciable effect on the value of the bank. Even if it would, that is a risk that should be fully taken into account by the bank's compensation policy unless the behavior would lead to the failure of the bank. In the few cases where a single rogue trader caused such losses (e.g., at Barings bank in 2005), the responsible individual went to jail.

Third, it is often very difficult to delay compensation until an investment or loan is fully realized. A trader in a bank who enters into long-term swap contracts (e.g., for interest rates, exchange rates, or credit default swaps), a loan officer who makes mortgage loans, or a venture lender who bets on a leveraged buy out will not see the results of his action for several years, perhaps as long as a decade or more. While it might in principle be desirable to withhold full compensation until the loan is repaid or the investment is completed, that is very difficult in an industry in which individuals change employers frequently.

Fourth, and perhaps most important, the combination of equity payments and delayed compensation would do little to deal with the excessive "tail risk" that is probably the greatest danger for individual institutions and for the financial sector as a whole. A portfolio manager or other risk taker in a financial firm can invest in ways that generally produce positive results within a year or two, combined with occasional small losses, but that also entails a small probability of an enormous loss because of leverage or of an unhedged derivative position. A series of 
traders who act in this way could have 20 years of generally positive returns for a firm. Each trader could be rewarded only when his investment was completed. But the process could nevertheless involve a small probability of a ruinous loss. The only way to stop such tail risk gambling is for the risk manager of the firm to understand the nature of the risk and to explicitly prevent it.

The compensation rules that the Fed has proposed would not succeed in reducing risk but might just transform the way the risk is taken or shift it to other institutions.

\section{Consumer Protection}

The Federal Reserve has a variety of consumer protection activities and regulations. Despite this, it is clear that some mortgage lenders and others involved in real estate took advantage of consumers who did not understand the implications of the loan obligations that they incurred (particularly the effect of teaser rates to be followed by sharp future increases). Many of the mortgage originators were outside the banking system, providing mortgage loans to individuals and then selling those loans to institutional investors.

Because of the problems suffered by many homeowners, there is political pressure to create a new separate Consumer Finance Protection Agency outside the Federal Reserve. It is not clear what the advantage would be of giving that responsibility to a new agency. The Fed's supervisory mandate could be extended to deal with all entities that make loans to households, requiring mortgage brokers as well as banks to use uniform loan agreements. A new agency whose sole purpose is consumer finance protection would lack the experience of the Fed and the quality of the Fed's staff. There is also the danger that it would be overzealous in "protecting" households in ways similar to those that led to excessive credit availability to subprime borrowers. The Federal Reserve would be in a better position to balance individual consumer protection and systemic considerations.

$\underline{\text { Resolution Authority }}$ 
The FDIC has the authority to close insolvent banks, to merge them into healthy banks or bank holding companies, and to use FDIC funds to close the gap between the assets and liabilities of the insolvent bank. The Treasury proposed in early 2009 that the FDIC's authority be extended to all "systemically significant" financial firms.

That proposal raises many issues that are beyond the scope of this essay. But it is relevant to ask whether the FDIC or the Federal Reserve should have such authority over the large bank holding companies that are supervised by the Federal Reserve. While the FDIC has experience in dealing with the relatively small organizations, the Fed seems much better able to deal with those large and complex organizations that it has already been supervising.

The Treasury proposal would leave ambiguous whether any given firm would be deemed to be sufficiently "systemically significant" to warrant extending the resolution authority to the FDIC. Giving the Fed authority to do so with all of the bank holding companies that it supervises would remove that uncertainty. The Fed's staff would probably be better able than the FDIC to deal with other large and complex financial firms, although a method of determining which firms were to be treated in this way would have to be decided.

The Treasury proposal contemplates using the FDIC's trust fund to finance these systemically significant resolutions, whether in paying debts to uninsured depositors or injecting equity capital to permit the organization to continue. This would of course be a very different use of the trust funds that are collected from the FDIC's member banks to finance payments to insured depositors. The large number of small institutions that pay into the FDIC fund would no doubt consider it unfair for their funds to be used in this way. If resolution authority is to be granted to the Fed (or indeed to any entity) some form of standby financing would have to be available.

\section{Conclusion}

The financial crisis and the severe economic downturn have generated calls for a range of fundamental changes in the financial system in general and to a variety of significant changes in the powers of the Federal Reserve. It is easy to understand why. After a decline of more than 
$\$ 10$ trillion of household sector wealth, the political system is looking to assign blame and punish those who are at fault.

There is no doubt that the Federal Reserve deserves some of the blame for the monetary policy that contributed to the mis-pricing of risk and the asset bubbles that caused the downturn. There is also no doubt that the Federal Reserve, like the other financial supervisors, did not give adequate attention to the capital position and asset quality of the institutions that they supervised.

But the reforms that are adopted now should aim to strengthen the performance of the Federal Reserve rather than to reduce its powers. The Fed should continue to manage monetary policy as it has in the past, should act as the nation's lender of last resort, should supervise the large bank holding companies, and should be given resolution authority over the institutions that it supervises. While a council of supervisors and regulators can play a useful role in dealing with macro prudential risks, it should not replace the central role of the Federal Reserve.

The virtually unlimited lending powers that the Fed has exercised in creating credit and in helping individual institutions during the past few years should now be restricted in duration and subjected to formal Treasury approval backed by Congressional pre-authorization of funds. The Fed's capital rules for commercial banks need to be strengthened by replacing the existing risk-based capital approach with a broader definition of risk and the introduction of contingent capital. A broader range of Fed regulations can contribute to overall stability, particularly in mortgage lending. Stronger Fed powers in dealing with non-bank creators of mortgage products and other lending authority would be better than the creation of a new consumer financial protection organization.

The Federal Reserve has made many mistakes in the near century since its creation in 1913. Fortunately it has learned from its past mistakes and contributed to the ongoing strength of the American economy. Further reforms at this time can continue that tradition.

Cambridge, MA

December 2009 